\title{
Strategi Pembelajaran Inkuiri dalam Peningkatan Kompetensi Analisis Unsur Cerita
}

\author{
M. Agus Ardianto \\ SMK Wachid Hasyim 2 Surabaya \\ Jl. Raya Sememi no 7 Kec Benowo Kota Surabaya, Indonesia \\ Pos-el : ardikotrek95@gmail.com
}

\begin{abstract}
Learning strategy is action plan (the series of activities including usage method of) and utilization of resources or force in learning. By the use of it and strategy in the education, the purpose of learning will possible. Needed education strategy right to be able to increase the interpretation students in learning analyze intrinsic element of stories. One between education and innovative strategy variatif is inquiry learning strategy. Learning inkuiri spi (strategy) is the learning activities who insists on the thought processes and analytical critically to seek and find your own the questionable a problem. Methods used in research the act of class ( ptk) this is a qualitative methodology that was produce descriptive analysis with the data collected in student of class xii study results ak 2 for two cycles. The result of this research is (1) in the first of 38, students there are students or $1334 \%$ at study analyzing the intrinsic and 25 students $66 \%$ not reaching study analyzing the intrinsic. In the second (2), students or 5019 increased to percent at study analyzing the intrinsic and 19 students $50 \%$ not reaching ketuntasan study analyzing the intrinsic.
\end{abstract}

Keywords: learning strategy, inquiry learning strategy, intrinsic

\begin{abstract}
Abstrak
Strategi pembelajaran merupakan rencana tindakan (rangkaian kegiatan) termasuk penggunaan metode dan pemanfaatan berbagai sumber daya atau kekuatan dalam pembelajaran. Dengan penggunaan strategi pembelajaran yang tepat dan sesuai standar, tujuan pembelajaran akan bisa dicapai. Dibutuhkan strategi pembelajaran yang tepat agar mampu meningkatkan daya interprestasi siswa dalam pembelajaran menganalisis unsur intrinsik cerita sejarah. Satu diantara strategi pembelajaran yang variatif dan inovatif adalah strategi pembelajaran inkuiri. Strategi pembelajaran inkuiri (SPI) adalah rangkaian kegiatan pembelajaran yang menekankan pada proses berpikir secara kritis dan analitis untuk mencari dan menemukan sendiri jawaban dari suatu masalah yang dipertanyakan. Metode yang digunakan dalam penelitian tindakan kelas (PTK) ini adalah metode kualitatif yang menghasilkan analisis deskriptif dengan data yang diperoleh berupa hasil belajar siswa kelas XII AK 2 selama dua siklus. Hasil penelitian ini adalah (1) pada siklus pertama dari 38 siswa, ada 13 siswa atau 34\% yang mencapai ketuntasan
\end{abstract}


belajar menganalisis unsur intrinsik dan 25 siswa atau 66\% yang tidak mencapai ketuntasan belajar menganalisis unsur intrinsik. (2) pada siklus kedua, meningkat menjadi 19 siswa atau 50\% yang mencapai ketuntasan belajar menganalisis unsur intrinsik dan 19 siswa atau 50\% yang tidak mencapai ketuntasan belajar menganalisis unsur intrinsik.

Kata Kunci: Strategi Pembelajaran, Strategi Pembelajaran Inkuiri, Unsur Intrinsik.

\section{PENDAHULUAN}

Pembelajaran atau pengajaran pada dasarnya merupakan kegiatan guru dalam menciptakan situasi agar siswa belajar. Melalui proses pembelajaran dapat terjadi perubahan, perkembangan, kemajuan, baik dalam aspek fisik-motorik, intelek, sosial-emosi maupun sikap dan nilai. Apabila makin besar, tinggi atau banyak perubahan dan perkembangan yang dapat dicapai oleh siswa, maka makin baiklah proses belajar. Agar tercipta pembelajaran atau pengajaran yang efektif, perlu digunakan pendekatan, model atau metode pembelajaran yang tepat (Sukmadinata, 2012: 103).

Pembelajaran sastra di sekolah merupakan bagian dari tujuan penyelenggaraan pendidikan nasional yaitu mewujudkan suasana dan proses pembelajaran agar peserta didik secara aktif mengembangkan potensi dirinya untuk memiliki kekuatan spiritual keagamaan, pengendalian diri, kepribadian, kecerdasan, akhlak mulia, dan keterampilan yang diperlukan dirinya di masyarakat, bangsa, dan negara.

$$
\text { Rahmanto (2005: 16) }
$$

menyatakan bahwa tujuan pembelajaran sastra di sekolah yaitu membantu keterampilan berbahasa, meningkatkan pengetahuan budaya, mengembangkan cipta dan rasa, kemudian menunjang pembentukan watak. Dalam bukunya, Rahmanto (2005: 16) menjelaskan bahwa terdapat empat tujuan pembelajaran sastra, yaitu : (1) pembelajaran sastra mencakup empat keterampilan bahasa, yaitu menyimak, berbicara, membaca, dan menulis, pembelajaran sastra yang dikaitkan langsung dengan fakta tentang kehidupan atau dihubungkan langsung dengan kehidupan seharihari seperti budaya pada masyarakat tertentu, (3) mengembangkan cipta dan rasa, dalam pembelajaran sastra kecakapan yang perlu dikembangkan adalah kecakapan yang bersifat indra, penalaran, afektif, sosial serta religius, (4) menunjang pembentukan watak, pembelajaran sastra mampu membina perasaan yang lebih tajam dibandingkan pelajaranpelajaran lainnya.

Tujuan pembelajaran sastra yang demikian belum dapat dicapai secara baik, karena beberapa pihak mengatakan bahwa pengajaran sastra belum memuaskan sehingga nilai UN 
mata pelajaran bahasa Indonesia pada kurikulum 2013 menurun dan masih di bawah standar yang ditetapkan. Salah satu faktor yang menyebabkan penurunan tersebut, yakni soal-soal UN yang semakin diselaraskan dengan tuntutan kurikulum. Salah satu tuntutan kurikulum dalam mata pelajaran bahasa Indonesia adalah kemampuan bahasa fungsional dalam konteks sosial (literasi fungsional). Kurikulum 2013 lebih menekankan pada pembentukan sikap/afektif. Untuk pembentukan sikap ini, hanya aspek-aspek seni yang mampu menjangkaunya, karena itu aspek sastra menjadi sesuatu yang mutlak disuguhkan kepada generasi melalui pendidikan di kelas. Fakta juga mengatakan bahwa sangat sedikit siswa yang berminat masuk jurusan bahasa, oleh karena itu pembelajaran yang diharapkan belum dapat dicapai secara maksimal lebih-lebih dalam usaha mempertahankan sastra sebagai satu kontrol sosial dan moral bagi siswa.

Selain itu, konsep pembelajaran yang menyenangkan juga menjadi satu diantara faktor dalam menunjang keberhasilan belajar dan selalu mencuat dalam dunia pendidikan. Konsep ini berorientasi pada interaksi edukatif antara guru dan siswa. Sebagai orientasi interaksi edukatif, praktik dari konsep ini dinilai mampu mewujudkan proses dan hasil belajar yang maksimal. Semua guru mata pelajaran disarankan mendesain pembelajaran yang menyenangkan, termasuk guru mata pelajaran bahasa Indonesia. Pembelajaran yang menyenangkan bisa diterapkan dari beberapa aspek. Pertama, penerapan model pembelajaran; Kedua, variasi metode pembelajaran; Ketiga, pendekatan dan teknik pembelajaran; Keempat, pemilihan media yang sesuai; Kelima, seni mengajar dari guru yang bersangkutan, termasuk kemampuan mengelola kelas dan penguasaan materi pembelajaran bahasa (sastra) Indonesia. Keberadaan kemampuan guru bahasa Indonesia di dalam Kurikulum 2013 perlu mendapat perhatian lebih. Selain kemampuan berbahasa, guru juga dituntut memiliki kemampuan bersastra. Kemampuan guru bukan cuma cakap berinteraksi, tetapi juga berkonsentrasi pada kreativitas, inovasi, dan memaksimalkan daya imajinasi. Ini sangat diperlukan karena materi sastra sangat menuntut guru yang kreatif, inovatif, dan imajinatif (Ismail, 2014).

Satu diantara pembelajaran sastra di sekolah adalah pembelajaran cerita. Pembelajaran cerita bertujuan agar siswa mampu mengenal suatu bentuk karya sastra dan memahami unsur-unsur yang membangun cerita tersebut. Aspek yang ditekankan pada pembelajaran cerita lebih tertuju pada unsur intrinsik yang terdapat dalam cerita. Unsur intrinsik meliputi tema, alur, penokohan, latar, sudut pandang, majas, dan nilai didik. Dengan memahami unsur tersebut siswa akan lebih mudah untuk memahami isi cerita. Sebagaimana pembelajaran sastra di sekolah yang belum memuaskan, kondisi pembelajaran cerita sejarah saat ini sudah cukup memuaskan. Dengan kondisi yang cukup memuaskan, siswa diharap lebih aktif lagi dalam pembelajaran sastra, salah satunya menemukan unsur intrinsik yang terkandung dalam cerita. 
Djamarah dan Zain (2006: 3) menyatakan bahwa strategi pembelajaran memunyai andil yang cukup besar dalam kegiatan mengajar. Kemampuan yang diharapkan dapat dimiliki anak didik, akan ditentukan oleh kerelevansian penggunaan suatu metode yang sesuai. Dengan penggunaan strategi pembelajaran yang tepat dan sesuai standar, tujuan pembelajaran akan bisa dicapai. Dibutuhkan strategi pembelajaran yang tepat agar mampu meningkatkan daya interprestasi siswa dalam pembelajaran menganalisis unsur intrinsik cerita sejarah. Satu diantara strategi pembelajaran yang variatif dan inovatif adalah strategi pembelajaran inkuiri. Strategi pembelajaran ini membuat siswa terpusat dengan materi yang sedang dibahas, memperkecil kesempatan siswa untuk bermain sendiri saat pelajaran, dan memberikan pengalaman belajar yang menarik dan bermakna bagi siswa. Strategi pembelajaran inkuiri juga dapat menghindarkan kebingungan siswa karena siswa dapat memperoleh jawaban berdasarkan kegiatan yang mereka lakukan sendiri. Dengan menggunakan strategi pembelajaran inkuiri siswa akan lebih mudah menganalisis unsur intrinsik cerita sejarah karena strategi ini dapat menumbuhkan motivasi dan rasa percaya diri, sehingga siswa merasa puas atas pekerjaannya sendiri.

Arikunto (2014: 104-105) menyatakan Penelitian Tindakan Kelas (PTK) adalah suatu pendekatan untuk meningkatkan pendidikan dengan melakukan perubahan ke arah perbaikan terhadap hasil pendidikan dan pembelajaran. Indikasi setidaknya tentang hal ini dapat terlihat di SMK Wachid Hasyim 2 Surabaya, nilai ratarata pembelajaran menganalisis unsur cerita sejarah siswa kelas XII adalah 70-74. Ada beberapa hal yang menyebabkan rendahnya nilai yang diperoleh oleh siswa tersebut, antara lain minat siswa dalam membaca teks cerita kurang, teks yang digunakan dalam cerita sejarah juga kurang menarik. Memerhatikan kondisi tersebut tampak bahwa guru dapat melaksanakan penelitian yang sumber masalahnya diangkat dari kegiatan nyata di kelasnya. Para guru sering menghadapi masalah yang berkaitan dengan proses pembelajaran di kelasnya dan sudah berupaya mengatasi. Namun, kemampuan untuk menuangkan ke dalam bentuk karya yang memenuhi syarat ilmiah sering belum maksimal.

Pada intinya PTK merupakan suatu penelitian yang akar permasalahannya muncul di kelas, dan dirasakan langsung oleh guru yang bersangkutan sehingga sulit dibenarkan jika ada anggapan bahwa permasalahan dalam penelitian tindakan kelas diperoleh dari persepsi atau lamunan seorang peneliti. Jenis penelitian tersebut sangat bermanfaat sebagai upaya untuk memperbaiki proses pembelajaran di kelas.

Sanjaya (2006: 196) menyatakan bahwa strategi pembelajaran inkuiri (SPI) adalah rangkaian kegiatan pembelajaran yang menekankan pada proses berpikir secara kritis dan analitis untuk mencari dan menemukan sendiri jawaban dari suatu masalah yang dipertanyakan. Proses berpikir itu sendiri biasanya dilakukan melalui tanya jawab antara guru dan siswa. Strategi pembelajaran 
ini sering juga dinamakan strategi heuristic, yang berasal dari bahasa yunani, yaitu heuriskein yang berarti saya menemukan.

Strategi pembelajaran inkuiri (SPI) berangkat dari asumsi bahwa sejak manusia lahir, manusia memiliki dorongan untuk menemukan sendiri pengetahuannya. Rasa ingin tahu tentang keadaan alam disekelilingnya merupakan kodrat manusia sejak ia lahir ke dunia. Sejak kecil manusia memiliki keinginan untuk mengenal segala sesuatu melalui indra pengecapan, pendengaran, penglihatan, dan inderaindera lainnya. Hingga dewasa keingintahuan manusia secara terus menerus berkembang dengan menggunakan otak dan pikirannya. Pengetahuan yang dimiliki manusia akan bermakna (meaningfull) manakala didasari oleh keinginantahuan itu. Dalam rangka itulah strategi inkuiri dikembangkan.

Ada beberapa hal yang menjadi ciri utama strategi pembelajaran inkuiri. Aspek yang pertama, strategi inkuiri menekankan kepada aktivitas siswa secara maksimal untuk mencari dan menemukan, artinya strategi inkuiri menempatkan siswa sebagai subjek belajar. Dalam proses pembelajaran, siswa tidak hanya berperan sebagai penerima pelajaran melalui penjelasan guru secara verbal, tetapi mereka berperan untuk menemukan sendiri inti dari materi pelajaran tersebut.

Aspek yang kedua, seluruh aktivitas yang dilakukan siswa diarahkan untuk mencari dan menemukan jawaban sendiri dari sesuatu yang dipertanyakan, sehingga diharapkan dapat menumbuhkan sikap percaya diri (self belief). Dengan demikian, strategi pembelajaran inkuiri menempatkan guru bukan sebagai sumber belajar, akan tetapi sebagai fasilitator dan motivator belajar siswa. Aktivitas pembelajaran biasanya dilakukan melalui proses tanya jawab antara guru dan siswa. Oleh sebab, itu kemampuan guru dalam menggunakan teknik bertanya merupakan syarat utama dalam melakukan inkuiri.

Aspek yang ketiga, tujuan penggunaan strategi pembelajaran inkuiri adalah mengembangkan kemampuan berpikir secara sistematis, logis, dan kritis, atau mengembangkan kemampuan intelektual sebagai bagian dari proses mental. Dengan demikian, dalam strategi pembelajaran inkuiri siswa tidak hanya dituntut agar menguasai materi pelajaran, akan tetapi cara mereka dapat menggunakan potensi yang dimilikinya. Manusia yang hanya menguasai pelajaran belum tentu dapat mengembangkan kemampuan berpikir secara optimal, namun sebaliknya, siswa akan dapat mengembangkan kemampuan berpikirnya apabila ia bisa menguasai materi pelajaran.

Seperti yang dapat disimak dari proses pembelajaran, tujuan utama pembelajaran melalui strategi inkuiri adalah menolong siswa untuk dapat mengembangkan disiplin intelektual dan keterampilan berpikir dengan memberikan pertanyaan-pertanyaan dan mendapatkan jawaban atas dasar ingin tahu mereka.

Strategi pembelajaran inkuiri merupakan bentuk pendekatan pembelajaran yang berorientasi kepada siswa (student centered 
approach). Dikatakan demikian, sebab dalam strategi ini siswa memegang peran yang lebih dominan dalam proses pembelajaran. Strategi pembelajaran inkuiri akan efektif apabila:

a. Guru mengharapkan siswa dapat menemukan sendiri jawaban dari suatu permasalahan yang ingin dipecahkan. Dengan demikian dalam strategi inkuiri penguasaan materi pelajaran bukan sebagai tujuan utama pembelajaran, akan tetapi yang lebih dipentingkan adalah proses belajar.

b. Jika bahan pelajaran yang akan diajarkan tidak berbentuk fakta atau konsep yang sudah jadi, akan tetapi sebuah kesimpulan yang perlu pembuktian.

c. Jika proses pembelajaran berangkat dari rasa ingin tahu siswa terhadap sesuatu.

d. Jika guru akan mengajar pada sekelompok siswa yang rata-rata memiliki kemauan dan kemampuan berpikir. Strategi inkuiri akan kurang berhasil diterapkan kepada siswa yang kurang memiliki kemampuan untuk berpikir.

e. Jika jumlah siswa yang belajar tidak terlalu banyak sehingga bisa dikendalikan oleh guru.

f. Jika guru memiliki waktu yang cukup untuk menggunakan pendekatan yang berpusat pada siswa.

Menurut Nurgiyantoro (2013: 30) unsur intrinsik adalah unsur-unsur yang membangun karya sastra itu sendiri. Unsur-unsur inilah yang menyebabkan suatu teks hadir sebagai teks sastra, unsur-unsur yang secara faktual akan dijumpai jika orang membaca karya sastra. Unsur intrinsik sebuah cerita sejarah adalah unsur-unsur yang (secara langsung) turut serta membangun cerita. Kepaduan antarberbagai unsur intrinsik inilah yang membuat sebuah cerita sejarah berwujud. Atau sebaliknya, jika dilihat dari sudut kita pembaca, unsur-unsur (cerita) inilah yang akan dijumpai jika kita membaca sebuah cerita sejarah. Unsur yang dimaksud, untuk menyebut sebagian saja misalnya, tema, alur, penokohan, latar, sudut pandang, majas, dan nilai didik.

\section{METODE PENELITIAN}

Metode penelitian yang dilakukan model penelitian tindakan kelas dengan empat tahapan yang dilalui, yaitu (1) perencanaan, (2) pelaksanaan, (3) pengamatan, dan (4) refleksi. Pengambilan data untuk penelitian ini dilakukan pada siswa kelas XII AK 2 yang berjumlah 38 siswa. Penelitian ini terbagi menjadi tiga siklus, siklus pertama dilaksanakan pada hari Senin,13 November 2018. Siklus kedua dilaksanakan pada hari Selasa, 14 November 2018.

Dalam penelitian ini subjek yang digunakan adalah siswa kelas XII AK 2. Peneliti memilih kelas XII AK 2 sebagai subjek penelitian karena di kelas tersebut siswa masih kesulitan dalam menemukan hal-hal penting dalam cerita sejarah, seperti menganalisis unsur intrinsik cerita sejarah. Selain itu, nilai rata-rata pembelajaran menganalisis unsur intrinsik cerita sejarah siswa kelas XII 
AK 2 masih dibawah KKM yaitu 70-74. Ada beberapa hal yang menyebabkan rendahnya nilai yang diperoleh oleh siswa tersebut, antara lain minta siswa dalam membaca teks cerita sejarah kurang dan teks yang digunakan kurang menarik.

\section{PEMBAHASAN}

\section{Proses Penggunaan Strategi Pembelajaran Inkuiri untuk Meningkatkan Kompetensi Menganalisis Unsur Intrinsik Cerita Sejarah}

Berdasarkan strategi penelitian pada bab sebelumnya, pembahasan kali ini adalah penyajian data berupa proses penggunaan strategi pembelajaran inkuiri untuk meningkatkan kompetensi menganalisis unsur intrinsik cerita sejarah terdiri dari empat tahap yaitu perencanaan, pelaksanaan, observasi, dan refleksi yang dilakukan selama tiga siklus.

\section{A. Siklus I}

1. Perencanaan

Pada perencanaan kali ini guru terlebih dahulu memperkenalkan kepada siswa tentang strategi pembelajaran inkuiri dan mempersiapkan segala sesuatu yang digunakan dalam penelitian, seperti mempersiapkan RPP, materi pembelajaran berupa teks cerita sejarah sesuai dengan jumlah kelompok yang sudah ditentukan.

\section{Pelaksanaan}

Pada pelaksanaan kali ini guru melaksanakan langkah-langkah sesuai dengan langkah-langkah yang sudah direncanakan dalam RPP dan menghitung hasil belajar siswa berupa nilai yang diperoleh dari penyebaran instrumen lembar cerita sejarah beserta 7 pertanyaan berbentuk tes uraian tentang unsur intrinsik.

\section{Observasi}

Selama kegiatan berlangsung, yang bertindak sebagai observer adalah peneliti. Peneliti melakukan tindakan berupa pencatatan terhadap aktivitas siswa dan rekapitulasi penilaian sikap selama pembelajaran berlangsung.

4. Refleksi

Guru melakukan identifikasi pengetahuan siswa terhadap materi pembelajaran menganalisis unsur intrinsik cerita sejarah dan melakukan tindakan-tindakan perbaikan dalam meningkatkan aktivitas siswa.

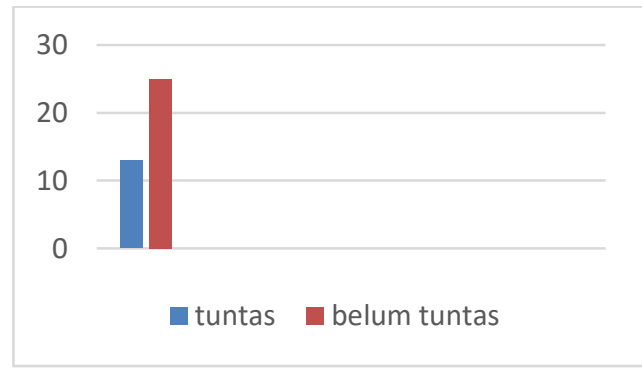

Diagram 4.1 Hasil Belajar Siswa

Dari kemampuan menganalisis unsur intrinsik cerita di atas diperoleh siswa yang mencapai kemampuan menganalisis unsur intrinsik cerita sejarah sebanyak 13 siswa atau 34\%, sedangkan yang belum mencapai kemampuan menganalisis unsur intrinsik cerita sejarah sebanyak 25 siswa atau 66\%. Dengan demikian masih banyak siswa yang belum mencapai nilai KKM yaitu 75. 
Namun, pembelajaran siklus pertama telah mencapai ketuntasan klaksikal.

\section{B. Siklus 2}

Kegiatan yang dilakukan pada siklus kedua sama halnya dengan siklus pertama, yaitu melakukan perencanaan, pelaksanaan, observasi, dan refleksi. Siklus kedua dilaksanakan karena hasil yang diperoleh pada siklus pertama tidak menunjukan hasil maksimal, masih banyak siswa yang mendapatkan nilai di bawah KKM.

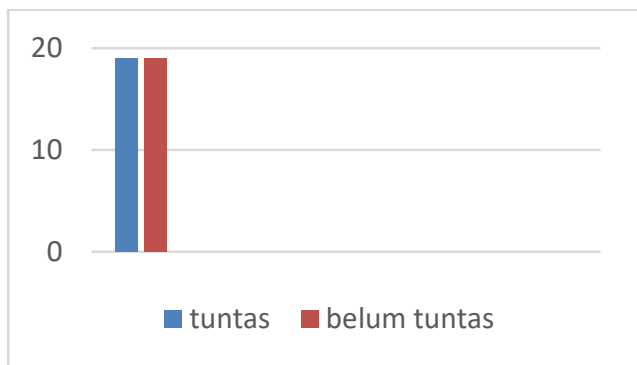

Diagram 4.2 Hasil Belajar Siswa

Setelah hasil tes siklus kedua dianalisis terungkap bahwa dari jumlah 13 siswa atau 34\% yang mencapai ketuntasan belajar pada siklus pertama, meningkat menjadi 19 siswa atau 50\%. Dari 25 siswa atau $66 \%$ yang belum mencapai kemampuan belajar pada siklus pertama, menurun menjadi 19 siswa atau 50\%. Namun, demikian pembelajaran siklus kedua telah mencapai ketuntasan klaksikal.

\section{Refleksi}

Kegiatan pembelajaran mulai dari apersepsi sampai dengan kegiatan pelatihan berjalan sesuai dengan kegiatan yang direncanakan. Kegiatan remidi pun juga dapat dilaksanakan pada waktu pembelajaran siklus kedua. Hal ini berarti pembelajaran siklus kedua berjalan lebih efisien.

Hasil tes dan observasi yang dilaksanakan pada siklus kedua ini menunjukkan adanya peningkatan aktivitas dan sikap siswa serta kemampuan dalam belajar. Selain itu kegiatan remidi juga efektif dalam membantu siswa mencapai kemampuannya. Namun peningkatan aktivitas siswa dan kemampuan menganalisis unsur intrinsik cerita sejarah pada siklus kedua ini menurut peneliti belum maksimal karena pembelajaran pada siklus kedua belum mencapai ketuntasan seluruh siswa tetapi telah memenuhi ketuntasan klasikal.

\section{SIMPULAN}

Berdasarkan pembahasan penggunaan strategi pembelajaran inkuiri untuk meningkatkan kompetensi menganalisis unsur intrinsik cerita siswa kelas XII SMK Wachid Hasyim Surabaya dapat disimpulkan sebagai berikut:

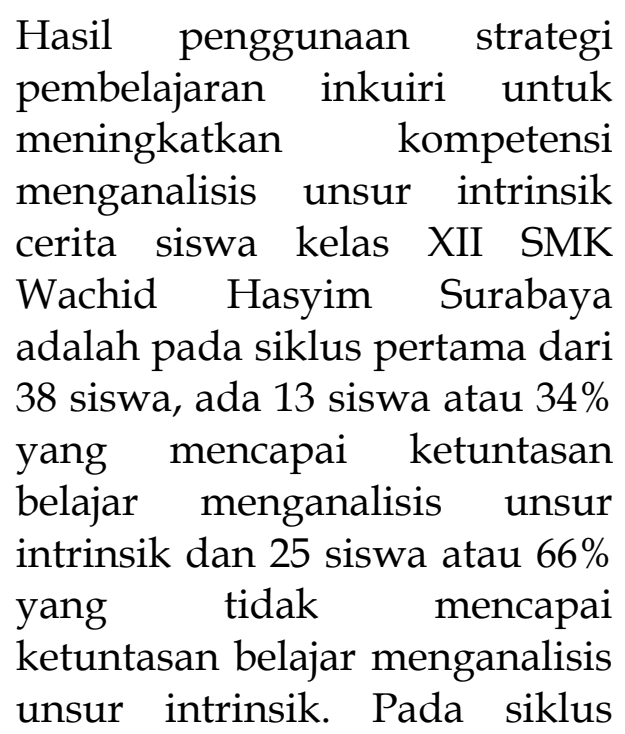


kedua, meningkat menjadi 19 siswa atau $50 \%$ yang mencapai ketuntasan belajar menganalisis unsur intrinsik dan 19 siswa atau $50 \%$ yang tidak mencapai ketuntasan belajar menganalisis unsur intrinsik.

\section{DAFTAR PUSTAKA}

Arikunto, Suharsimi, dkk. (2014). Penelitian Tindakan Kelas. Jakarta: PT Bumi Aksara

Djamarah, Syaiful Bahri dan Zain, Aswan. (2006). Strategi Belajar Mengajar. Jakarta: Rineka Cipta

Ismail, Musa. (21 September 2014). Pembelajaran (Bahasa) Sastra dalam Kurikulum 2013. http://m.riaupos.co/2204spesial-pembelajaran-(bahasa)- sastra-dalam-kurikulum2013.html. Diakses pada tanggal 22 Januari 2019

Nurgiyantoro, Burhan. (2013). Teori Pengkajian Fiksi. Yogyakarta: Gadjah Mada University Press

Rahmanto, B. (2005). Metode Pengajaran Sastra. Yogyakarta: Kanisius

Sanjaya, Wina. (2006). Strategi Pembelajaran Berorientasi Standar Proses Pendidikan. Jakarta: Kencana Prenada Media

Sukmadinata. (2012). Penggunaan Strategi Pembelajaran Inkuiri Untuk Meningkatkan Kompetensi Menganalisis Unsur Intrinsik Cerpen. Skripsi tidak diterbitkan. Surabaya: Fakultas Bahasa dan Sains Universitas Wijaya Kusuma Surabaya 